\title{
Prevalencia de anticuerpos contra HTLV-1 en una población negra de Colombia
}

\author{
María C. Navas ${ }^{1}$, Antonio Iglesias², Beatriz M. Martínez¹, Luis Caraballo
}

\begin{abstract}
Resumen
El virus linfotrópico humano 1 (HTLV-1) ha sido asociado con la leucemia de células $T$ del adulto (ATL) y la paraparesia espástica tropical (PET) o mielopatía asociada con HTLV-1 (HAM). Aunque la prevalencia de anticuerpos contra el HTLV-1 ha sido descrita en diversos países, especialmente en Japón, poco se conoce acerca de este marcador de contacto viral en nuestra población. En este artículo describimos la ausencia de niveles de anticuerpos anti-HTLV-1 en el suero, medidos por la prueba de ELISA, en una población negra de la costa atlántica de Colombia. Nuetros hallazgos sugieren que: a) este grupo descendiente de Africa no se ha expuesto al virus; b) puede ser que algunos de los individuos incluidos en el estudio estén en período de incubación y, que debido a su juventud, no fue posible demostrar una respuesta humoral contra el virus; $y, c)$ como ha sido descrito en otros estudios, la prevalencia de anticuerpos anti-HTLV1 varía entre las diferentes regiones de Colombia.
\end{abstract}

\section{Summary}

Human T-lymphotropic virus 1 (HTLV-1) is associated with adult T-cell leukaemia (ATL) and tropical spastic paraparesis (TSP) or HTLV-1-associated myelopathy (HAM). Although the prevalence of antibodies to HTLV-1 has been described in several places, specially Japan, little is known about this virus-contact marker in our population. Here we report the absence of measurable levels of serum anti-HTLV-1 antibodies, as detected by ELISA, in an isolated black population of the Atlantic coast of Colombia. Our findings suggest that: a) this African descendant group has not been exposed to the virus; b) it may be that some of the subjects included in the study are in the incubation period, but due to their youth, it was not possible to demonstrate any humoral response; and, c) as it has been described in other studies, the prevalence of HLTV-1 antibodies is also different in some regions of Colombia.

El virus linfotrópico humano (HTLV-1) fue el primer retrovirus humano aislado y caracterizado (1). Sus vías de transmisión son las transfusiones sanguíneas, las relaciones sexuales y a través de la leche materna (2). El HTLV-1 se ha asociado con diversas enfermedades como la leucemia de las células $T$ del adulto (ATL), la

1 Instituto de Investigaciones Inmunológicas, Universidad de Cartagena.

2 Instituto Nacional de Salud, Santafé de Bogotá, D.C. paraparesia espástica tropical(PET) ola mielopatía asociada con HTLV-1 (HAM), el síndrome de Sézary, las enfermedades broncopulmonares, las artropatías y la uveítis, entre otras. Sin embargo, los datos epidemiológicos disponibles señalan al HTLV-1 como agente causal solamente de ATL y PET $(2,3)$. La ATL o linfoma endémico, presenta una alta incidencia en los habitantes de la región suroccidental del Japón $(2,5)$.

La endemicidad de la infección por este virus, también ha sido demostrada en países del Cari- 
be, Africa, Suramérica y, en menor proporción, el sur de los Estados Unidos e Italia (6). En países como Colombia, Martinica, Jamaica, Panamá y Venezuela se asocia con más frecuencia a un síndrome neurológico crónico progresivo, que afecta los miembros inferiores, llevando al paciente a presentar debilidad en los miembros y dificultad para caminar (6-8).

Esta enfermedad se conoce como paraparesia espástica tropical (PET) y en el Japón recibe el nombre de mielopatía asociada con HTLV-1 (HAM). Con base en el análisis de las secuencias de cepas de HTLV-1 aisladas en Japón, Estados Unidos, Caribe y Nueva Guinea, se ha sugerido que posiblemente este virus tuvo su origen en la región indomelanésica y que, posteriormente, se diseminó al resto del mundo (9).

Otros investigadores consideran como sitio de origen al Japón. También ha sido postulada la hipótesis de que en el continente africano haya tenido origen el HTLV-1 y que, posteriormente, llegó al Japón a través de los portugueses que se habrían infectado en sus viajes por Africa (2). La migración de africanos a partir de la región central del continente como esclavos hacia el continente americano sería la explicación de la alta seroprevalencia del virus en estos países, donde la gran mayoría de pacientes son de raza negra o tienen ancestros de esta raza (10).

En el caso de Colombia, la población de la costa pacífica posee en su mayoría ancestros de raza negray presentan una seroprevalencia para HTLV1 de 7,1 a $14,3 \%$ en pacientes mayores de 40 años. El foco endémico se encuentra situado más exactamente en Tumaco, Nariño, en donde se presentan con frecuencia casos de PET entre la población seropositiva (8). En la costa atlántica sólo se conoce un informe de la prevalencia de anticuerpos contra HTLV-1, este estudio se realizó en población de donantes de sangre, encontrando una seropositividad de $2,4 \%$ entre los donantes examinados (11).

\section{Materiales y métodos}

Un total de 95 muestras de plasma, conservadas a $-7^{\circ} \mathrm{C}$, obtenidas de muestras de sangre de habitantes del corregimiento de Palenque (ubicado a 45 minutos de Cartagena, Colombia), fueron sometidos a la prueba de ELISA para investigar la presencia de anticuerpos contra HTLV-1. Se utilizó el estuche de HTLV-1 EIA de Abbott, inmunoensayo cualitativo que utiliza perlas de poliestireno cubiertas con el sonicado del cultivo del virus en la línea celular HUT-102.B2. Para las condiciones del ensayo se siguieron las recomendaciones de la casa comercial.

\section{Resultados}

La población examinada tiene un promedio de edad de 30 años y todos son de raza negra. Ninguna de las 95 muestras examinadas presentó anticuerpos contra el virus en la prueba de EIA.

\section{Discusión}

Este trabajo se realizó con el fin determinar la prevalencia de anticuerpos contra HTLV-1 en una población de raza negra que se ha mantenido sin mezclarse con otros grupos raciales desde su llegada a América procedente de Africa. Esta población africana habría venido infectada con este retrovirus, si se considera cierta la hipótesis de que el continente africano es el sitio de origen del HTLV-1. Podría suponerse cierto grado de endemicidad y, por tanto, la presencia de estos anticuerpos ya que en la costa pacífica colombiana, donde habitan grupos negros con un probable origen común a los de Palenque, se han detectado casos de PET y anticuerpos contra HTLV-1.

El hecho de no encontrar estos anticuerpos en ninguna de las muestras puede explicarse por la edad de los individuos incluidos en este estudio, que fue, en promedio, de treinta años. Se sabe que pueden pasar varios años después de la infección con el virus para que aparezcan niveles detectables de anticuerpos. En los focos endémicos de la costa pacífica, la mayoría de las personas seropositivas han adquirido la infección a través de la leche materna o por contacto sexual y presentan el mayor porcentaje de seropositividad entre los 40 y 60 años (12).

Por otro lado, existía la posibilidad de este resultado dado que en la población de Palenque, la cual conocemos de cerca a través de varios trabajos sobre genética, no se han observado signos o síntomas que hagan sospechar cuadros 